\title{
AGRESIVITAS PAJAK YANG DIPENGARUHI OLEH KOMPENSASI EKSEKUTIF, KONEKSI POLITIK, PERTUMBUHAN PENJUALAN, LEVERAGE DAN PROFITABILITAS
}

\section{TAX AGGRESSIVITY AFFECTED BY EXECUTIVE COMPENSATION, POLITICAL CONNECTION, SALES GROWTH, LEVERAGE AND PROFITABILITY}

\author{
Ernie Riswandari ${ }^{1)^{*}}$, Kevin Bagaskara ${ }^{2)}$ \\ Universitas Bunda Mulia ${ }^{1)}$, Universitas Bunda Mulia ${ }^{21}$ \\ eriswandari@bundamulia.ac.id ${ }^{l}$, ernieriswandari@gmail.com ${ }^{2}$
}

\begin{abstract}
This research aims to prove that tax aggressiveness is influenced by executive compensation, political connections, sales growth, leverage, and profitability. The annual reports of BUMN \& BUMS companies in the non-financial sector are secondary data used in this study and by using the purposive sampling method in selecting the sample. The method of analysis used in this study is multiple linear regression. The result shows that the executive compensation variable has a positive effect on tax aggressiveness. Political connection variables, sales growth, and leverage have a negative effect on tax aggressiveness, while the profitability variable has no effect on tax aggressiveness.
\end{abstract}

Keywords: Executive compensation, political connection, sales growth, leverage, profitability, tax aggressiveness

\begin{abstract}
ABSTRAK
Penelitian ini bertujuan untuk membuktikan tindakan agresivitas pajak yang dipengaruhi oleh kompensasi eksekutif, koneksi politik, pertumbuhan penjualan, leverage, dan profitabilitas. Laporan tahunan perusahaan BUMN \& BUMS sektor non keuangan merupakan data sekunder yang digunakan dalam penelitian ini dan dengan menggunakan metode purposive sampling dalam pemilihan sample. Metode analisis yang digunakan dalam penelitian ini adalah regresi linier berganda diperoleh hasil bahwa variabel kompensasi eksekutif berpengaruh positif terhadap agresivitas pajak. Variabel koneksi politik, pertumbuhan penjualan dan leverage berpengaruh negatif terhadap agresivitas pajak, sedangkan variabel profitabilitas tidak berpengaruh terhadap agresivitas pajak.
\end{abstract}

Kata Kunci : Kompensasi eksekutif, koneksi politik, pertumbuhan penjualan, leverage, profitabilitas, agresivitas pajak

*Corresponding author

Email: ernieriswandari@gmail.com

DOI: https://doi.org/10.33369/j.akuntansi.10.3.261-274

\section{PENDAHULUAN}

Sebuah negara tentunya memiliki berbagai macam sumber penerimaan negara salah satunya adalah sumber daya alam, namun kandungan sumber daya alam itu cenderung akan habis karena itu Pemerintah harus mencarai alternative sumber penerimaan yang lainnya salah satunya adalah pajak yang diharapkan menjadi sumber penerimaan negara yang paling potensial mengingat jumlah penduduk Indonesia jumlahnya banyak dan cenderung terus meningkat. Bila diasumsikan penduduk tersebut nantinya akan bekerja dan akan memperoleh penghasilan dimana penghasilan merupakan obyek dari pajak sehingga pajak merupakan sumber penerimaan negara yang sangat potensial untuk dapat meningkatkan penerimaan negara dan jumlah penduduk yang banyak akan menjadi salah satu daya tarik bagi investor untuk berinvestasi di Indonesia. Dengan banyaknya perusahaan yang tumbuh dan berkembang nantinya akan berdampak pada perolehan penerimaan pajak bagi negara.

Terdapatnya perbedaan persepsi tentang pajak antara perusahaan dan Pemerintah dimana menurut persepsi perusahaan, pajak merupakan beban yang harus ditanggung perusahaan dan 
akan mengurangi perolehan laba bersih yang diterima perusahaan sehingga perusahaan akan berupaya agar beban pajak yang harus dikeluarkan perusahaan dapat dikeluarkan seminimum mungkin, sedangkan bagi Pemerintah pajak merupakan sumber penerimaan negara sehingga Pemerintah akan terus berupaya meningkatkan pendapatannya dari pajak. Akibat terdapatnya perbedaan persepsi tersebut mengakibatkan timbulnya perilaku perusahaan melakukan upaya meminimumkan beban pajaknya melalui perencanaan pajak yang dilakukannya kita mengenalnya sebagai agresivitas pajak yaitu seberapa agresif perusahaan melakukan upaya untuk meminimumkan beban pajaknya, sehingga masih terdapat beberapa perusahaan yang melakukan upaya meminimumkan beban pajak yang sangat agresif sekali yang akhirnya perusahaan tersebut menjadi terjerat hukum akibat perilaku perusahaan tersebut terkait kewajiban perpajakannya. Beberapa kasus yang bisa kita lihat terkait dengan hal ini contohnya kasus yang terjadi pada perusahaan Bumi Resources, Kaltim Coal (KPC), dan Arutmin diindikasi melakukan tindakan praktik penghindaran pajak dengan jumlah Rp.2,176 Triliun, dengan rincian KPC sebagai penghindar pajak terbesar yakni Rp. 1,5 Triliun, kemudian BUMI Resources dengan total Rp. 376 Miliyar, dan Arutmin senilai Rp. 300 Miliyar (tempo.com,2010). Masalah penunggakan pajak juga kerap terjadi di BUMN seperti yang pernah dialami kasus penunggakan pajak oleh PT. Semen Tonasa dan PT. Garuda Indonesia namun kini perusahaan tersebut telah menyelesaikan tunggakan pajaknya (Kompas.com, 2010).

Menurut Frank et. al.(2009) dalam Ariyani dan Harto (2014) agresivitas pajak merupakan perilaku perusahaan melakukan upaya untuk menurunkan beban pajaknya melalui skema tax avoidance atau melalui tax evasion. Agresivitas pajak yang dilakukan perusahaan akan memberikan peluang bagi manajemen yang bersifat oportunis melakukan tindakan agresivitas pajak yang dapat membahayakan bagi perusahaan dan akan mengancam keberlangsungan usaha perusahaan (Lumbantouran (1996) dalam Ariyani dan Harto (2014)) Semua kebijakan atau keputusan yang diterapkan perusahaan tentuanya atas dasar pepengetahuan pimpinan yaitu para pimpinan eksekutif termasuk juga keputusan untuk melakukan penghindaran pajak perusahaan (Hanafi dan Harto, 2014).

Tindakan agresivitas pajak yang dilakukan sebuah perusahaan diprediksi kemungkinan karena dipengaruhi beberapa factor seperti kompensasi eksekutif, koneksi politik, pertumbuhan penjualan, leverage dan profitabilitas. Menurut Halioui (2016) kompensasi eksekutif terhadap agresivitas pajak hasilnya menunjukan bahwa kompensasi eksekutif berpengaruh negatif terhadap agresivitas pajak, menunjukan bahwa semakin tinggi kompensasi eksekutif, semakin rendah tingkat agresivitas pajak. Namun menurut Hanafi (2014) hasil penelitian yang telah dilakukan di Indonesia menemukan bahwa kompensasi eksekutif berpengaruh negatif terhadap CETR menunjukan bahwa semakin tinggi kompensasi eksekutif akan berdampak pada upaya penghindaran ataupin penggelapan pajak semakin meningkat.

Sebuah perusahaan yang memiliki koneksi politik akan memiliki resiko deteksi yang rendah bila perusahaan melakukan tindakan agresivitas pajak karena politisi akan melindungi dan perusahaan memiliki akses informasi yang lebih baik bila akan terjadi perubahan peraturan perpajakan, demikian juga perolehan tekanan dari pasar modal akan transparansi pada perusahaan tersebut akan menurun dan adanya koneksi politik akan mempermudah untuk mendapatkan akses ke pemerintah pusat (Kim \& Zhang, 2015). Menurut Wicaksono (2017) bahwa koneksi politik berhubungan positif terhadap agresivitas pajak, adanya koneksi politik melalui hubungan komisaris berpengaruh positif dan signifikan terhadap agresivitas pajak menunjukan bahwa adanya koneksi politik yang dilakukan oleh perusahaan baik itu BUMN maupun BUMS digunakan untuk melakukan pendekatan dengan Pemerintah untuk menghindari pemeriksaan pajak, pengajuan pengurangan denda pajak maupun tindakan lain yang tergolong tax evasion atau tax agreesiveness. namun dalam penelitian yang dilakukan Mulyani (2014) bahwa koneksi politik berhubungan negatif terhadap penghindaran pajak 
bahkan dalam penelitian yang dilakukan oleh Hijriani (2014) bahwa koneksi politik tidak berpengaruh terhadap penghindaran pajak.

Penjualan yang dilakukan perusahaan atas produk yang dihasilakan dari kegiatan bisnis utamanya menjadi perhatian penting bagi perusahaan karena hal tersebut akan berdampak langsung pada perolehan penghasilan dan pada akhirnya pada perolehan laba perusahaan sehingga perusahaan akan menaruh perhatian dan dukungan yang serius pada bagian tersebut dengan mengoptimalkan sumber daya yang dimiliki perusahaan. Perusahaan akan selalu terus memantau pertumbuhan penjualan yang dapat dicapai oleh perusahaan.Dalam kaitannya dengan masalah perpajakan terjadinya pertumbuhan penjualan yang cenderung meningkat yang kan berpengaruh terhadap perolehan laba dan pada akhirnya akan berdampak juga terhadap pada beban pajak perusahaan akan berpotensi bagi sebuah perusahaan melakukan praktik tax avoidance atau penghindaran pajak. Penelitian yang di lakukan oleh Hidayat (2018) menunjukan bahwa pertumbuhan penjualan berpengaruh negatif dan signifikan terhadap penghindaran pajak, sedangkan penelitian yang dilakukan oleh Dewinta \& Setiawan (2016) menyatakan bahwa pertumbuhan penjualan berpengaruh positif terhadap penghindaran pajak.

Faktor lain yang diprediksi dapat mempengaruhi perusahaan melakukan upaya meminumumkan beban pajak yang biasa dikenal dengan agresivitas pajak salah satunya adalah leverage karena leverage merupakan ratio yang menunjukan seberapa besar asset perusahaan yang dibiayai dari hutang. Penelitian terkait dengan leverage yang dilakukan oleh Sukmawati \& Rebecca (2016) menunjukan hasil bahwa leverage memiliki pengaruh signifikan terhadap agresivitas pajak, namun tidak sejalan atau bertolak belakang dengan penelitian yang dilakukan oleh Hidayat (2018) dan juga Dewinta \& Setiawan (2016) yang menyimpulkan bahwa leverage tidak berpengaruh terhadap penghindaran pajak.

Profitabilitas yang diperoleh perusahaan juga diperkirakan akan mempengaruhi agresivitas pajak. Penelitian tentang pengaruh profitabilitas terhadap agresivitas pajak beberapa kali telah dilakukan. Dalam penelitian Nugraha (2015), Prasista (2016) menghasilkan bahwa profitabilitas memiliki pengaruh terhadap agresivitas pajak yang dapat diinterpretasikan bahwa besarkan profit atau laba yang diperoleh sebuah perusahaan akan berpengaruh terhadapan besarnya beban pajak yang harus dibayar perusahaan akan meningkat, hal tersebut akan berpotensi bagi sebuah perusahaan melakukan tindakan agresivitas pajak. Namun hal ini berlawanan dengan penelitian yang dihasilkan oleh Permata (2018) yang menunjukan bahwa profitabilitas tidak berpengaruh terhadap perilaku penghindaran pajak.

Berdasarkan hasil penelitian terdahulu dimana masih terdapat perbedaan hasil pada kompensasi eksekutif, koneksi politik, pertumbuhan penjualan, leverage dan profitabilitas yang menurut peneliti hal tersebut merupakan suatu research gap sehingga factor-faktor tersebut masih perlu diteliti bagaimana pengaruhnya terhadap agresivitas pajak. Sehingga peneliti ingin melakukan penelitian untuk mengetahui apakah terdapat pengaruh kompensasi eksekutif , koneksi politik, pertumbuhan penjualan, leverage dan profitabilitas berpengaruh terhadap agresivitas pajak secara parsial.

\section{KERANGKA TEORITIS DAN HIPOTESIS}

\section{Agency Theory}

Teori yang mendasari penelitian ini atau sebagai grand teorinya adalah agency Theory. Agency theory atau teori keagenan berisi tentang hubungan pihak yang memiliki perusahaan atau atasan (principal) dengan bawahan (agent) yang terikat dalam suatu kontrak kerja untuk melaksankan tugas mewakili pemilik perusahaan (principal) yang mencakup tentang pendelegasian wewenang dalam pengambilan keputusan oleh agent (Jensen dan Meckling, 1976 dalam Sufia dan Riswandari, 2018). Pemegang saham dan manajemen masing-masing memiliki kepentingan dalam perusahaan. Penyatuan kepentingan pihak tersebut cenderung menimbulkan masalah dalam bidang keuangan. Terdapatnya perbedaan kepentingan tersebut 
diakibatkan karena adanya asimetri informasi yaitu kondisi tidak berimbangnya informasi yang dimiliki antara principal dengan agent sehingga hal tersebut dimanfaatkan oleh agent agar apa yang menjadi kepentingan pribadinya dapat tercapai.

\section{Teori Akuntansi Positif}

Teori akuntansi positif juga turut mendasari penelitian ini dimana dalam teori akuntansi positif menurut Watt \& Zimmerman, (1990) dalam Sufia dan Riswandari (2018) teori akuntansi positif mengarahkan pada pencarian keteraturan empiris dan menjelaskan hal tersebut dari studi empiris yang dilakukan dari waktu ke waktu, memberikan kontribusi bahwa ada sebuah hubungan antara pilihan akuntansi perusahaan dan variabel perusahaan lain, seperti leverage, ukuran, dan tanda-tanda hubungan yang sebagian besar konsisten di seluruh penelitian, sehingga dapat diinterpretasikan bahwa manajer cenderung akan memilih prosedur akuntansi yang dapat merealisasikan apa yang diinginkan oleh perusahaan.

\section{Agresivitas Pajak}

Menurut Frank et.al (2009) dalam Sufia dan Riswandari (2018) bahwa agresivitas pajak adalah tindakan yang dilakukan oleh sebuah perusahaan untuk meminimumkan beban pajak yang harus dibayarnya dengan cara memanipulasi penghasilan kena pajak melalui perencanaan pajak yang dapat atau tidak dapat dipertimbangkan sebagai penghindaran pajak yang menyimpang (fraudulent tax evasion). Agresivitas pajak merupakan suatu kegiatan perencanaan pajak (tax planning) untuk mengurangi tingkat pajak yang efektif dan melalui perencanaan pajak yang dilakukan perusahaan terjadi proses pengendalian agar terhindar dari dampak pengenaan pajak yang tidak dikehendaki.

Agresivitas pajak berdasarkan hasil dari penelitian yang telah dilakukan sering diproxikan dengan Effective Tax Rates (ETR). ETR merupakan salah satu indicator yang dapat digunakan untuk mengidentifikasi adanya agresifitas pajak, bila sebuah perusahaan memiliki ETR mendekati nol dan cenderung menurun maka perusahaan tersebut disinyalir bahwa perusahaan tersebut semakin agresif melakukan usaha untuk memperkecil beban pajak atau bahkan mungkin melakukan penggelapan pajak, sebaliknya bila nilai ETR menjauhi 0 dan cenderung naik maka dapat diartikan bahwa tingkat agresivitas pajaknya cenderung turun atau semakin tidak agresif dalam melakukan upaya untuk memperkecil beban pajak perusahaan (Lanis, Richardson, 2012).

\section{Kompensasi Eksekutif}

Kompensasi merupakan imbalan atau penghargaan yang diberikan kepada karyawan atas kontribusi dari pekerjaan yang telah diberikannya kepada perusahaan dimana penghargaan tersebut dapat berupa financial baik diberikan secara langsung atau tidak langsung (Yusuf,2015). Menurut Harto dan Hanafi (2014) kompensasi yang diberikan kepada manajemen sebagai upaya untuk mengendalikan perilaku manajemen.

\section{Koneksi Politik}

Menurut Purwati dan Sugiyarti (2007) koneksi politik adalah suatu kondisi dimana terjalin suatu hubungan antar pihak tertentu dengan pihak yang memiliki suatu kepentingan dalam politik yang digunakan untuk mencapai suatu hal tertentu yang menguntungkan kedua belah pihak. Sebuah perusahaan yang memiliki koneksi politik bila perusahaan yang bersangkutan memiliki hubungan istimewa dengan Pemerintah. Hubungan istimewa antara pemilik perusahaan dengan pemerintah adalah tokoh politik yang terkemuka yang merupakan anggota dewan baik itu di pemerintahaan pusat maupun daerah ataupun sebagai anggota partai politik (Gomez, 2009 dalam Widagdo \& Pranoto, 2016). 


\section{Pertumbuhan Penjualan}

Pertumbuhan penjualan merupakan terjadinya pencapaian perolehan tingkat penjualan pada suatu perusahaan dari waktu ke waktu berdasarkan data penjualan yang dimiliki perusahaan. Pertumbuhan penjualan dapat diketahui melalui rasio antara selisih penjualan tahun sekarang di kurangi penjualan tahun sebelumnya lalu dibagi dengan penjualan tahun sebelumnya (Fahmi, 2014 dalam Hidayat, 2018).

\section{Leverage}

Untuk memenuhi kebutuhan modalnya sebuah perusahaan dapat memperoleh dengan cara menerbitkan saham atau dapat juga dengan cara berhutang. Biaya modal yang timbul dari penerbitan saham adalah dengan membagikan deviden sedangkan biaya modal yang dikeluarkan dari meminjam atau berhutang adalah membayar bunga. Dalam perpajakan beban bunga dari hutang yang dimiliki perusahaan dapat digunakan sebagai pengurang dalam perhitungan pajak penghasilannya, sedangkan pembagian deviden yang dikeluarkan perusahaan tidak dapat digunakan sebagai pengurang. Guna mengetahui seberapa besar asset yang dimiliki perusahaan yang didanai dari hutang dapat kita lihat dari tingkat leverage yaitu membandingkan beban hutang terhadap asset atau ekuitasnya. Kecenderungan semakin tinggi rasio leverage menunjukan bahwa semakin besar sumber pendanaan perusahaan yang berasal dari hutang dan akan mengakibatkan besarnya beban bunga yang harus dibayar perusahaan namun hal tersebut dapat dalam perhitungan pajak penghasilan badan perusahaan bahwa beban bunga merupakan termasuk biaya yang dapat dikurangkan. Semakin tinggi beban bunga yang boleh dikurangkan akan berpengaruh terhadap besarnya pajak yang harus dibayar perusahaan (Darmawan \& Sukartha, 2014) dalam Permata (2018).

\section{Profitabilitas}

Salah satu indikator bahwa sebuah perusahaan memiliki kinerja yang baik adalah dengan melihat tingkat kemampuan perusahaan menghasilkan laba pada periode tersebut dapat terlihat dari tingkat rasio profitabilitas yang dimiliki perusahaan. Investor akan lebih tertarik untuk berinvestasi pada perusahaan yang memiliki tingkat profitabilitasnya yang tinggi. Namun dalam perhitungan pajak penghasilan badan besarnya profitabilitas atau laba bersih yang diperoleh perusahaan adalah sebagai dasar dalam menentukan besarnya pajak penghasilan badan yang harus dibayar perusahaan (Rodriguez dan Arias, 2012 dalam Nugraha dan Meiranto, 2015.

\section{Hipotesis}

\section{Pengaruh Kompensasi Eksekutif terhadap Agresivitas Pajak}

Kompensasi eksekutif adalah imbalan yang diberikan kepada pihak manajemen atas kontribusi yang telah diberikan kepada perusahaan dan juga sebagai upaya untuk mengendalikan perilaku manajemen (Yusuf,2015). Kecenderungannya dalam penentuan besarnya kompensasi eksekutif dilihat dari besarnya pencapaian kinerja dari para manajemen dengan berpedoman pada anggaran yang telah ditetapkan dalam penilaian tersebut Terdapatnya kondisi asimetri informasi dimanfaatkan oleh manajemen untuk memenuhi kepentingan pribadinya agar kinerjanya terlihat baik sehingga agent dalam hal ini eksekutif akan memproleh peningkatan kompensasi dari principal (Merchant and Stede, 2014). Berbagai upaya akan dilakukannya agar agen atau eksekutif tersebut dapat memperoleh kompensasi seperti yang diharapkan. Salah satu upaya yang bisa dilakukan adalah dengan meminimukan beban pajak. Berdasarkan hasil penelitian yang terdahulu menurut Harto dan Hanafi (2017) bahwa kompensasi eksekutif berpengaruh positif signifikan terhadap agresivitas pajak yang artinya bahwa semakin tinggi kompensasi eksekutif maka akan menyebabkan tingkat agresifitasnya 
cenderung rendah yang akan terlihat pada nilai ETR cenderung naik Sehingga dapat ditarik hipotesis sebagai berikut:

$\mathrm{H}_{1}$ : Kompensasi Eksekutif berpengaruh positif signifikan terhadap agresivitas pajak

\section{Pengaruh Koneksi Politik terhadap Agresivitas Pajak}

Menurut Handayani,(2013) dan Faccio, (2006) dalam Ardiana (2016) perusahaan yang dimiliki atau dipimpin oleh anggota parlemen, menteri, atau orang yang berkaitan erat dengan politikus atas atau partai politik artinya perusahaan tersebut memiliki hubungan yang dekat dengan Pemerintah sehingga dianggap memiliki koneksi politik. Hasil Penelitian yang dilakukan oleh Wicaksono (2017) bahwa agresivitas pajak yang dipengaruhi secara positif oleh koneksi politik maka perusahaan tersebut berpotensi akan melakukan pendekatan dengan Pemerintah untuk menghindari pemeriksaan pajak, pengurangan denda pajak maupun tindakan lain yang tergolong pengindaran pajak maupun penggelapan pajak sehingga dapat diintepretasikan bahwa sebuah perusahaan yang memiliki koneksi politik berpotensi akan melakukan tindakan agresivitas pajak. Berdasarkan uraian tersebut maka dapat ditarik hipotesis sebagai berikut :

$\mathrm{H}_{2}$ : Koneksi politik berpengaruh positif signifikan terhadap agresivitas pajak.

\section{Pengaruh Pertumbuhan Penjualan terhadap Agresivitas Pajak}

Terjadinya tren penjualan yang cenderung meningkat menunjukan bahwa telah terjadi peningkatan penjualan. Terjadinya peningkatan penjualan tentunya akan diiringi dengan meningkatnya perolehan laba perusahaan (Dewinta dan Setiawan,2016). Hal tersebut tentunya akan berdampak pada besarnya beban pajak yang harus dibayar perusahaan. Menurut Hidayat (2018) berdasarkan hasil penelitiannya bahwa adanya pengaruh yang negatif pertumbuhan penjualan terhadap penghindaran pajak yang dapat diinterpretasikan bahwa semakin tinggi pertumbuhan penjualan maka akan semakin rendah nilai ETR yang cenderung turun berarti bahwa perusahaan akan semakin agresif melakukan penghindaran pajak yang akan dilakukan perusahaan. Sehingga dapat ditarik hipotesis :

$\mathrm{H}_{3}$ : Pertumbuhan penjualan berpengaruh positif signifikan terhadap agresivitas pajak.

\section{Pengaruh Leverage terhadap Agresivitas Pajak}

Leverage merupakan seberapa besar asset yang dimiliki perusahaan yang sumber pendanaannya berasal dari hutang. Biaya modal yang timbul dari hutang yang dimiliki perusahaan adalah beban bunga, sedangkan beban bunga merupakan salah satu biaya yang dapat digunakan sebagai pengurang dalam menghitung besarnya Pajak Penghasilan Badan (PPh Badan) yang harus dilunasi perusahaan. Menurut Liu dan Cao (2007) dalam Ardyansyah (2014) perusahaan yang memiliki leverage yang tinggi akan memiliki effectif tax rate (ETR) cenderung menurun. Menurut Lanis dan Richardson (2007) dalam Nugraha \& Meiranto (2015) terdapatnya hubungan negatif antara leverage dan ETR dapat diinterpretasikan bahwa perusahaan berpotensi untuk meningkatkan tingkat leveragenya agar penghasilan kena pajaknya cenderung menurun sehingga beban pajak yang ditanggung menjadi cenderung menurun. Sehingga dapat ditarik hipotesis :

$\mathrm{H}_{4}$ : leverage memiliki pengaruh positif signifikan terhadap agresivitas pajak.

\section{Pengaruh Profitabilitas terhadap Agresivitas Pajak}

Tingkat perolehan laba perusahaan dapat diukur dengan menggunakan rasio profitabilitas yaitu rasio yang digunakan untuk melihat kemampuan perusahaan dalam menghasilkan laba dari aktivitas normal bisnisnya (Hery, 2014, p.192), sedangkan dasar pengenaan pajak dihitung berdasarkan perolehan laba bersih perusahaan pada periode tersebut sehingga akan berpotensi sebuah perusahan melakukan tindakan agresivitas pajak. 
Menurut Nugraha(2015) bahwa profitabilitas memiliki pengaruh positif terhadap agresivitas pajak. Menurut Prasista,(2016) menyatakan jika kemampuan perusahaan dalam menghasilkan laba meningkat maka besarnya pajak yang harus dibayar juga meningkat. Hal tersebut menyebabkan perusahaan akan berusaha mencari cara untuk menurunkan beban pajaknya. Berdasarkan hal tersebut maka dapat ditarik hipotesis sebagai berikut; $\mathrm{H}_{5}$ : Profitabilitas memiliki pengaruh positif signifikan terhadap agresivitas pajak

\section{METODE PENELITIAN}

Perusahaan-perusahaan BUMN dan BUMS sektor non keuangan yang terdaftar di Bursa Efek Indonesia (BEI) periode 2013-2017 merupakan subyek penelitian dalam penelitian ini. Obyek dalam penelitian ini adalah agresivitas pajak yang dipengaruhi oleh kompensasi eksekutif, koneksi politik, pertumbuhan penjualan, leverage dan profitabilitas. Terdapat lima variabel independen dalam penelitian ini diantaranya kompensasi eksekutif (X1), koneksi politik (X2), pertumbuhan penjualan (X3), leverage (X4), dan profitabilitas (X5), sedangkan agresivitas pajak merupakan variabel dependen (Y). Berikut adalah pengoperasian variabel dalam penelitian ini:

Tabel 1 Operasionalisasi Variabel

\begin{tabular}{|c|c|}
\hline Variabel & Proxy \\
\hline Kompensasi eksekutif & Ln(Kompensasi eksekutif dalam setahun) \\
\hline Koneksi Politik & $\begin{array}{l}\text { Variabel ini diproksikan dengan variabel Dummy, bila terdapat } \\
\text { koneksi } \\
\text { politik }=1 \text {, dan bila tidak terdapat }=0 .\end{array}$ \\
\hline Pertumbuhan penjualan & 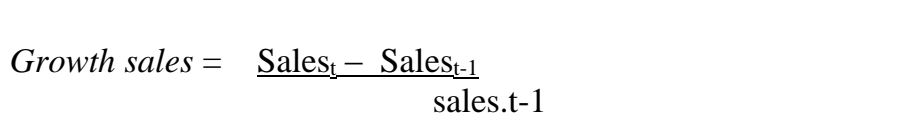 \\
\hline Leverage & DTA $=\frac{\text { Total hutang }}{\text { Total aset }}$ \\
\hline Profitabilitas & ROA = laba sebelum pajak / total aset \\
\hline Agresivitas pajak & ETR = Income tax expense / income before tax \\
\hline
\end{tabular}

Populasi dalam penelitian ini adalah laporan tahunan pada perusahaan BUMN dan BUMS sektor non keuangan yang terdaftar di Bursa Efek Indonesia (BEI) periode 2013-2017. Metode yang digunakan untuk pengambilan sampel dalam penelitian ini adalah purposive sampling dengan berdasarkan pada kriteria yang telah ditetapkan dalam penelitian ini yaitu perusahaan BUMN dan BUMS sektor non keuangan yang mempublikasikan laporan keuangan dan laporan tahunan dengan data yang lengkap dari tahun 2013-2017, menggunakan mata uang rupiah, memiliki kelengkapan data terkait variable yang digunakan dalam penelitian ini. Berdasarkan kriteria tersebut maka diperoleh jumlah sampel perusahaan yang memenuhi kriteria sebanyak 24 perusahaan dengan waktu pengamatan selama 5 tahun.

Penelitian ini melakukan analisis statistik deskriptif, pengujian asumsi klasik pada model regresi serta pengujian hipotesis dengan menggunakan bantuan software STATA versi 14.2 untuk mengelolah data kuantitatif yang telah terkumpul. Penelitian ini tergolong penelitian kuantitatif sehingga diperlukan pengujian untuk menguji hubungan variabel bebas terhadap variabel terikat dimana dalam penelitian ini tujuannya untuk melihat pengaruh variable independen terhadap variabel dependent, maka dilakukan uji regresi jadi data yang digunakan dalam penelitian ini telah lolos uji asumsi klasik yang meliputi uji normalitas, multikolinieritas, heterokedastisitas dan autokolerasi dengan demikian dapat dilanjutkan uji regresi. Untuk dapat menjawab rumusan permasalahan yang ada dalam penelitian ini maka uji-uji yang dilakukan adalah uji determinasi (Adjusted $\mathrm{R}^{2}$ ) dan uji $\mathrm{F}$. 
AGRESIVITAS PAJAK YANG DIPENGARUHI OLEH KOMPENSASI EKSEKUTIF, KONEKSI POLITIK, PERTUMBUHAN PENJUALAN, LEVERAGE DAN PROFITABILITAS

Ernie Riswandari ${ }^{1)}$, Kevin Bagaskara ${ }^{2)}$

\section{HASIL DAN PEMBAHASAN}

\section{Statistik Deskriptif}

Berdasarkan tabel statistik deskriptif yang berada di lampiran terdapat sebanyak 24 perusahaan BUMN \& BUMS sektor non keuangan yang terdaftar di Bursa Efek indonesia (BEI). Periode pengamatan yang dilakukan peneliti dengan menggunakan laporan keuangan tahunan yang telah diaudit oleh auditor independen pada tahun 2013-2017. Maka dari itu diperoleh total data yang diobservasi sebanyak 120 data laporan keuangan tahunan perushaan BUMN \& BUMS setor non-keuangan yang terdaftar di (BEI).

Kompensasi eksekutif pada jumlah data (obs) sebesar 120, perusahaan yang mempunyai nilai minimum 20.89 dimiliki oleh PT Lionmesh Prima Tbk pada tahun 2013, sedangkan nilai maksimum 26.18 yang dimiliki oleh PT Telekomunikasi Indonesia (Persero) Tbk pada tahun 2017. Dari analisa tersebut dapat disimpulkan bahwa nilai rata-rata kompensasi eksekutif pada perusahaan selama periode penelitian adalah 23.64. Nilai standar deviasi pada kompensai eksekutif yaitu 1.04 .

Koneksi politik pada jumlah data (obs) sebesar 120, perusahaan yang mempunyai nilai minimum 0 yang artinya tidak memiliki koneksi politik yang diantara 24 perusahaan yang menjadi sampel penelitian, terdapat 15 perusahaan yang mempunyai nilai minimum 0 . Sedangkan nilai maksimum 1 yang artinya memiliki koneksi politik dimiliki oleh 9 perusahaan lainnya. Dari analisa tersebut dapat disimpulkan nilai rata-rata koneksi politik adalah 0.375. Nilai standar deviasi pada koneksi politik yaitu 0.49 .

Pertumbuhan penjualan pada jumlah data (obs) sebesar 120, perusahaan yang mempunyai nilai minimum -0.3 dimiliki oleh PT lionmesh Prima Tbk pada tahun 2015, sedangkan nilai maksimum 0.9 dimiliki oleh PT Waskita Karya (Persero) Tbk. Dari analisa tersebut dapat disimpulkan bahwa nilai rata-rata pertumbuhan penjualan selama periode penelitian adalah 0.1084. Nilai standar deviasi pada pertumbuhan penjualan yaitu 0.1993 .

Leverage pada jumlah data (obs) sebesar 120, perusahaan yang mempunyai nilai minimum 0.07 dimiliki oleh PT Pelayaran Nelly Dwi Putri Tbk pada tahun 2017, PT Industri Jamu dan Farmasi Sido Muncul Tbk pada tahun 2014 dan 2015. Sedangkan nilai maksimum 0.84 dimiliki oleh PT Adhi Karya (Persero) Tbk pada tahun 2013 dan 2014, PT PP (Persero) Tbk pada tahun 2013 dan 2014, PT Indal Alumunium Industry Tbk pada tahun 2013 dan 2014. Nilai rata-rata leverage adalah 0.44. standar deviasi pada leverage yaitu 0.23.

Profitabilitas pada jumlah data (obs) sebesar 120, perusahaan yang mempunyai nilai minimum 0.01 dimiliki oleh PT Timah Tbk pada tahun 2015, PT Adi Sarana Armada Tbk pada tahun 2015, PT Indal Alumunium Industry pada tahun 2013, PT Lion Metal Works pada tahun 2017, PT Lionemesh Prima Tbk pada tahun 2015. Sedangkan nilai maksimum 0.41 dimiliki oleh PT Indocement Tunggal Prakarsa Tbk pada tahun 2014. Dari analisa tersebut dapat disimpulkan bahwa nilai rata-rata profitabilitas pada perusahaan selama periode penelitian sebesar 0.09. Standar deviasi pada profitabilitas yaitu 0.0687 .

Agresivitas pajak pada jumlah data (obs) sebesar 120, perusahaan yang mempunyai nilai minimum 0.01 dimiliki oleh PT Acset Indonusa Tbk pada tahun 2015 dan 2016, PT Total Bangun Persada Tbk pada tahun 2017. Sedangkan nilai maksimum 0.57 dimiliki oleh PT Bukit Asam Tbk tahun 2017. Nilai rata-rata agresivitas pajak adalah 0.26. Standar deviasi pada agresivitas pajak yaitu 0.12 .

\section{Pengujian Regresi Linier Berganda}

Berdasarkan data yang diperoleh dan telah lolos uji asumsi klasik maka dapat dilakukan uji regresi linier berganda seperti yang terlihat pada hasil pengujian regresi linier berganda seperti yang terdapat pada lampiran bahwa pada kolom Coef. Untuk kompensasi eksekutif 0,361072, koneksi politik 0,0531924, pertumbuhan penjualan -0,1803367, leverage 
0.02052659, profitabilitas 0,3515534 , dan konstanta/_cons terdapat nilai 0,9937793. _cons merupakan konstanta persamaan regresi, sedangkan kompensasi eksekutif, koneksi politik, pertumbuhan penjualan, leverage, dan profitabilitas adalah konstanta untuk X1, X2, X3, X4, dan X5, sehingga persamaan linier berganda dalam penelitian ini adalah sebagai berikut :

$$
\begin{aligned}
\mathrm{ETR}= & 0,9937793+(0,361072) \mathrm{X} 1+0,0531924 \mathrm{X} 2+(0,1803367) \mathrm{X} 3+0.02052659 \mathrm{X} 4+ \\
& 0,3515534 \mathrm{X} 5+€(\text { tingkat eror }) .
\end{aligned}
$$

\section{Uji koefisien Determinasi}

Berdasarkan tabel hasil pengujian koefisien determinasi terlihat bahwa nilai koefisien determinasi yang disesuaikan (Adjusted $R$ Square) adalah sebesar 0.1764 menunjukan bahwa variabel kompensasi eksekutif, koneksi politik, pertumbuhan penjualan, leverage, dan profitabilitas mampu menjelaskan perubahan agresivitas pajak sebesar 17,64\% sedangkan sisanya sebesar $82.36 \%$ merupakan pengaruh dari variabel independen di luar persamaan model regresi dalam penelitian ini.

\section{Uji Signifikasi Parameter Individual (Uji Statistik t)}

Berdasarkan hasil uji T guna untuk mengetahui bagaimanakah hubungan antara variable bebas yaitu kompensasi eksekutif, koneksi politik, pertumbuhan penjualan, leverage dan profitabilitas terhadap variable terikatnya yaitu agresivitas pajak seperti yang terlihat pada table hasil pengujian hipotesis yang ada di lampiran bahwa kompensasi eksekutif memiliki koefisien -0,361072 dengan tingkat signifikansi 0,003 , koneksi politik memiliki nilai koefisien 0,531924 dengan tingkat signifikansi 0,000 , nilai koefisien pertumbuhan penjualan $-0,1803367$ dengan tingkat signifikansi 0,002 , nilai koefisien untuk leverage 0,02052659 dengan tingkat signifikansi 0,000 dan untuk variabel profitabilitas memiliki koefisien 0,3515534 dengan tingkat signifikansi 0,062.

\section{Pembahasan}

\section{Pengaruh Kompensasi Eksekutif Terhadap Agresivitas Pajak}

Berdasarkan tabel hasil pengujian regresi terlihat bahwa nilai koefisien regresi dari variabel kompensasi eksekutif yaitu -0.0361072 dengan nilai probabilitas atau tingkat signifikansi sebesar 0,003 < 0,05 yang artinya semakin tinggi kompensasi eksekutif maka akan semakin rendah nilai Effectif Tax Rate (ETR), artinya tingkat agresivitas pajak semakin tinggi, jadi dapat disumpulkan bahwa kompensasi eksekutif berpengaruh positif terhadap agresivitas pajak maka dengan demikian $\mathrm{H}_{1}$ diterima $\mathrm{H}_{0}$ ditolak Penelitian ini sejalan dengan penelitian yang dilakukan oleh Harto dan Hanafi (2014) yang menyatakan bahwa tingginya kompensasi eksekutif akan berpengaruh positif terhadap penghindaran pajak perusahaan. Penelitian ini juga sejalan dengan penelitian yang dilakukan oleh Armstrong et al., (2012) yang menyatakan bahwa kompensasi yang tinggi ditujukan untuk mengurangi beban pajak yang harus dibayarkan perusahaan.

Berdasarkan hasil di atas, dapat disimpulkan bahwa tingginya kompensasi yang diberikan kepada eksekutif atau manajemen dapat menjadi salah satu cara perusahaan melakukan agresivitas pajak, hasil temuan tersebut sejalan dengan teori agency dimana antara perusahaan dengan Pemerintah memiliki kepentingan yang berbeda dengan memanfaatkan adanya asimetri informasi tentang data perusahaan untuk meminimumkan beban pajak.

\section{Pengaruh Koneksi Politik Terhadap Agresivitas Pajak}

Berdasarkan tabel hasil pengujian regresi, diketahui bahwa nilai koefisien regresi variabel koneksi politik adalah sebesar 0.0531924 dengan nilai probabilitas sebesar $0,033<$ 
0,05. Yang artinya $\mathrm{H}_{0}$ diterima dan $\mathrm{H}_{2}$ ditolak karena arah hubungan kedua variable tersebut tidak sesuai namun memiliki pengaruh signifikan signifikan. Hasil menunjukan bahwa variabel koneksi politik memiliki pengaruh negative terhadap agresivitas pajak artinya koneksi politik yang cenderung naik akan menyebabkan nilai ETR cenderung naik yang artinya bahwa terdapatnya koneksi politik yang semakin kuat akan menyebabkan tindakan agresivitas pajak di perusahaan tersebut menjadi menurun atau tidak agresif. Penelitian ini sesuai dengan penelitian yang dilakukan oleh Pranoto dan Widagdo (2016) yang menyatakan bahwa koneksi politik berpengaruh negatif terhadap penghindaran pajak. Hasil ini juga sejalan dengan penelitian Zhang (2012) yang menemukan hubungan negatif antara koneksi politik dengan penghindaran pajak. Hasil penelitian ini juga sesuai dengan peraturan Mentri Keuangan Nomor 71/PMK.03/2010. Peraturan ini menggambarkan kepercayaan kepada perusahaan yang mayoritas pemegang sahamnya adalah pemerintah tidak melakukan tindakan penghindaran terhadap pajak, artinya perusahaan yang sebagian besar sahamnya dimiliki oleh pemerintah tingkat agresivitas pajaknya akan semakin rendah. Kedekatan ataupun koneksi yang dimiliki perusahaan kepada pemerintah justru membuat perusahaan semakin berhati-hati dalam mengambil keputusan atau kebijakan untuk mendapatkan citra yang baik dari masyarakat, karena tentu saja untuk jangka panjang masyarakat akan mempertimbangkan untuk menggunakan produk atau jasa yang dikeluarkan perusahaan atau berinvestasi kepada perusahaan atau tidak.

\section{Pengaruh Pertumbuhan Penjualan Terhadap Agresivitas Pajak}

Berdasarkan tabel hasil pengujian regresi, diketahui besarnya nilai koefisien regresi pertumbuhan penjualan adalah -0.1803367 dengan nilai probabilitas sebesar 0,002 < 0,05 . Artinya $\mathrm{H}_{0}$ ditolak $\mathrm{H}_{3}$ diterima yaitu pertumbuhan penjualan memiliki pengaruh positif terhadap agresivitas pajak, yang artinya semakin tinggi pertumbuhan penjualan akan berdampak pada nilai ETR nya semakin kecil yang artinya bahwa tingkat agresivitas pajak yang semakin tinggi. Penelitian ini sejalan dengan penelitian yang dilakukan oleh Dewinta dan Setiawan (2016) dan Hidayat (2018) yang menyatakan pertumbuhan penjualan berpengaruh positif terhadap penghindaran pajak, pertumbuhan penjualan pada suatu perusahaan menunjukan bahwa semakin besar volume penjualan, maka dari itu laba yang akan dihasilkan juga akan meningkat yang berarti bahwa semakin tinggi tingkat pertumbuhan maka akan menyebabkan perusahaan akan semakin agresif melakukan upaya untuk meminimumkan beban pajak perusahaan. Hasil penelitian ini sesuai dengan teori agensi, pihak manajemen akan berusaha mengelola beban pajak penghasilan perusahaan seminimum mungkin agar tidak mengurangi perolehan kompensasi atau bonus atas kinerjanya sebagai akibat dari laba perusahaan yang meningkat yang berasal dari pertumbuhan penjualan yang dapat menimbulkan beban pajak yang lebih besar.

\section{Pengaruh leverage Terhadap Agresivitas Pajak}

Berdasarkan tabel hasil pengujian regresi, diketahui besarnya nilai koefisien regresi variabel leverage adalah sebesar 0.02052659 dengan nilai probabilitas sebesar $0,000<0,05$, yang artinya $\mathrm{H}_{0}$ diterima dan $\mathrm{H}_{4}$ ditolak dimana arah hubungan kedua variable tersebut tidak sesuai dengan hipotesis namun memiliki pengaruh yang signifikan. Hasil menunjukan bahwa leverage berpengaruh negatif dan signifikan terhadap agresivitas pajak diamana semakin tinggi tingkat leverage maka semakin tinggi pula nilai ETR yang artinya adalah semakin menurun tingkat agresivitas pajak. Penelitian ini mendukung penelitian Dharma dan Ardiana (2016) yang menyatakan leverage berpengaruh negatif terhadap penghindaran pajak, karena semakin tinggi leverage perusahaan cenderung meningkatkan laba. Penelitian ini juga sejalan dengan penelitian yang dilakukan oleh Nugraha dan Meiranto (2015) yang menyatakan bahwa leverage 
berpengaruh negatif signifikan terhadap agresivitas pajak karena tingkat modal perusahaan yang dibiayai melalui hutangnyanya tinggi dimana dari hutang akan muncul beban bunga dimana menurut perpajakan beban bunga dapat digunakan sebagai pengurang sehingga akan menyebabkan penghasilan kena pajaknya menjadi menurun dan akhirnya beban pajak yang harus dibayar menjadi menurun sehingga perencanaan pajak yang dilakukan perusahaan tidak terlalu agresif. Hasil penelitian ini sejalan dengan teori akuntansi positif bahwa perusahaan akan memilih prosedur akuntansi yang dapat membantu merealisasikan apa yang diinginkan perusahaan.

\section{Pengaruh Profitabilitas Terhadap Agresivitas Pajak}

Berdasarkan tabel hasil uji regresi, diketahui besarnya nilai koefisien regresi variabel profitabilitas senilai 0.3515534 dengan probabilitas sebesar $0,062>0,05$. Yang berarti $\mathrm{H}_{0}$ diterima $\mathrm{H}_{5}$ ditolak yaitu variabel profitabilitas tidak memiliki pengaruh positif terhadap agresivitas pajak. Hasil penelitian ini sejalan dengan penelitian yang dilakukan oleh Nugraha dan Meiranto (2015) yang menyimpukan dalam penelitiannya bahwa profitabilitas berpengaruh positif namun tidak signifikan terhadap agresivitas pajak dikarenakan adanya reformasi dibidang perpajakan. Penelitian ini juga mendukung penelitian yang dilakukan oleh permata, dkk (2018) yang menyebutkan bahwa profitabilitas tidak berpengaruh terhadap penghindaran pajak karena dalam menghitung pajak penghasilan perusahaan perhitungannya harus berdasarkan pada laporan keuangan perusahaan sehingga hal tersebut sangat beresiko karena akan mudah untuk diketahui oleh fiskus sehingga tidak berpengaruh terhadap agresivitas pajak, kemungkinan perusahaan akan lebih tertarik cari cara melalui sesuatu yang sulit untuk ditelusuri oleh fiskus dengan memanfaatkan adanya asimetri informasi antara perusahaan dengan Pemerintah, maka dengan demikian hasil penelitian ini sesuai dengan teori agensi.

\section{KESIMPULAN DAN SARAN}

Penelitian ini bertujuan untuk mengetahui pengaruh variabel kompensasi eksekutif, koneksi politik, pertumbuhan penjualan, leverage, dan profitabilitas terhadap agresivitas pajak pada perusahaan BUMN \& BUMS sektor non keuangan yang terdaftar di Bursa Efek Indonesia diperoleh hasil bahwa variabel kompensasi eksekutif memiliki pengaruh positif terhadap agresivitas pajak, artinya bahwa semakin tinggi kompensasi eksekutif maka akan menyebabkan nilai ETR menurun yang maknanya adalah tingkat agresivitas pajaknya menjadi meningkat. Koneksi politik memiliki pengaruh negatif signifikan terhadap agresivitas pajak, yang artinya bahwa semakin tinggi koneksi politik maka akan menyebabkan nilai ETR meningkat yang maknanya bahwa tingkat agresivitas pajaknya menjadi menurun. Variabel pertumbuhan penjualan memiliki pengaruh negatif signifikan terhadap agresivitas pajak, artinya pertumbuhan penjualan berpengaruh positif terhadap agresivitas pajak yang artinya bahwa semakin meningkatnya pertumbuhan penjualan maka akan berpengaruh terhadap menurunnya nilai ETR yang maknanya bahwa tingkat agresivitas pajaknya menjadi meningkat. Variabel leverage memiliki pengaruh negatif terhadap agresivitas pajak, artinya bahwa semakin tinggi nilai leverage maka nilai ETR menjadi semakin tinggi sehingga dapat diinterpretasikan bahwa tingkat agresivitas pajaknya menjadi menurun. Variable Profitabilitas tidak memiliki pengaruh positif terhadap agresivitas pajak yang artinya bahwa perusahaan alan mencari alternative lain yang untuk meminimumkan beban pajak pada sesuatu yang sulit untuk ditelusuri oleh fiskus.

Saran yang dapat diberikan peneliti yang dapat digunakan sebagai bahan pertimbangan bagi pembaca atau peneliti selanjutnya, adalah penelitian ini hanya menggunakan pengukuran kepemilikan saham pemerintah untuk mengukur variabel koneksi politik sebuah perusahaan, oleh karena itu mungkin masih ada ukuran lain untuk melihat koneksi politik sebuah perusahaan agar koneksi politik sebuah perusahaan dapat dilihat dari berbagai aspek 
AGRESIVITAS PAJAK YANG DIPENGARUHI OLEH KOMPENSASI EKSEKUTIF, KONEKSI POLITIK, PERTUMBUHAN PENJUALAN, LEVERAGE DAN PROFITABILITAS

Ernie Riswandari ${ }^{1)}$, Kevin Bagaskara ${ }^{2)}$

\section{DAFTAR PUSTAKA}

Ardyansyah, Danis. 2014. Pengaruh Size, Leverage, Profitability, Capital Intensity Ratio dan Komisaris Independen Terhadap Effective Tax Rate (ETR). Fakultas Ekonomika dan Bisnis Universitas Diponegoro. Semarang.

Ariyani, N. F., \& Harto, P. (2014). Pengaruh Mekanisme Pengawasan Stakeholder terhadap Tindakan Agresivitas Pajak. Dipenogoro Journal of Accounting, 3(4), 1.

Armstrong, C. S., Blouin, J. L., \& Larcker, D. F. (2012). The incentives for tax planning. Journal of Accounting and Economics 53 , 391-411.

Dewinta, I. A., \& Setiawan, P. E. (2016). pengaruh ukuran perusahaan, umur perusahaan, profitabilitas, leverage, dan pertumbuhan penjualan terhadap tax avoidance. E-Jurnal Akuntansi Universitas Udayana (14).3. , 1584-1613.

Dharma, I. M., \& Ardiana, P. A. (2016). pengaruh leverage, intensitas aset tetap, ukuran perusahaan, dan koneksi politik terhadap tax avoidance. E-Jurnal Akuntansi Universitas Udayana,(15)1 . 584-613.

Fahmi, I (2014), ”Analisa Kinerja Keuangan, : Cetakan ketiga, Bandung, Alfabeta.

Halioui, K., Neifar, S., \& Abdelaziz, F. B. (2016). Corporate governance, CEO compensation and tax aggressiveness: Evidence from American firms listed on the NASDAQ 100. Review of Accounting and Finance, (15)4 , 445-462.

Hanafi, U., \& Harto, P. (2014). analisis pengaruh kompensasi eksekutif, kepemilikan saham eksekutif dan preferensi risiko eksekutif terhadap penghindaran pajak perusahaan. diponegoro journal of accounting,(3)2, 1-11.

Handayani, Desi. 2013. Pengaruh Kecakapan Manajerial, Set Kesempatan Investasi dan Kepemilikan Pemerintah Terhadap Tarif Pajak Efektif. Jurnal Akuntansi Keuangan dan Bisnis.(6), Desember 2013, Hal: 26-35.

Hery. (2014). Analisis Laporan Keuangan. Jakarta: PT Grasindo.

Hidayat, W. W. (2018). pengaruh profitabilitas, leverage dan pertumbuhan terhadap penghindaran pajak: studi kasus perusahaan manufaktur di indonesia . Jurnal Riset Manajemen dan Bisnis (JRMB) Fakultas Ekonomi UNIAT,(3)1. 19-26.

Hijriani, Anisa Nadia et.al. (2014). Pengaruh Koneksi Politik, Dewan Komisaris dan Karakteristik Perusahaan terhadap Penghindaran Pajak (Perusahaan BUMN yang terdaftar di BEI). Jurnal Reviu Akuntansi dan Keuangan,(4)1. 525-534.

Kieso, D. E., Jerry J. W., Warfield, T.P. (2011) Accounting Principles. 10Th Edition. Hoboken: John Wiley \& Sons, Inc.

Kim, C., \& Zhang, L. (2016). Corporate Political Connections and Tax Aggressiveness. Contemporary Accounting Research (33) 1. 78-114.

Kompas.com

Lanis, Richardson(2012), Corporate social responsibility and tax aggressiveness : a test of legitimacy theory, Journal of Applied AccountingResearch

Mulyani, S., Darminto, \& N.P, M. W. (2013). pengaruh karakteristik perusahaan, koneksi politik dan reformasi perpajakan terhadap penghindaran pajak (studi pada perusahaan manufaktur yang terdaftar di bursa efek tahun 2008-2012). Jurnal Fakultas Ilmu Administrasi Universitas Brawijaya .

Nugraha, N. B., \& Meiranto, W. (2015). pengaruh corporate social responsibility, ukuran perusahaan, profitabilitas, leverage dan capital intensity terhadap agresivitas pajak (studi empiris pada perusahaan non keuangan yang terdaftar di bursa efek indonesia 20122013). diponegoro journal of accounting,(4) 4. 1-14.

Peraturan Mentri Keuangan Nomor 71/PMK.03/2010

Permata, A. D., Nurlaela, S., \& W, E. M. (2018). Pengaruh Size, Age, Profitability, Leverage dan Sales Growth Terhadap Tax Avoidance. Jurnal Akuntansi dan Pajak, 19(01), 10-20. 
Pranoto, B. A., \& Widagdo, A. K. (2016). pengaruh koneksi politik dan corporate governance terhadap tax aggressiveness. Syariah Paper Accounting FEB UMS .

Prasista, P. M., \& Setiawan, E. (2016). Pengaruh Profitabilitas dan Pengungkapan Corporate Social Responsibility terhadap Agresivitas Pajak Penghasilan Wajib Pajak Badan. EJurnal Akuntansi Universitas Udayana,(17)3 , 2120-2144.

Purwanti, S. M., \& Sugiyarti, L. (2017). Pengaruh Intensitas Aset Tetap, Pertumbuhan Penjualan dan Koneksi Politik Terhadap Tax Avoidance. jurnal riset akuntansi dan keuangan, 5 (3) , 1625-1642.

Siregar, Sarsin. "Ditjen Pajak Temukan 7 Modus Penghindaran Pajak Properti". http://medanbisnisdaily.com/news/read/2013/09/11/50052/ditjen_pajak_tem ukan_7modus_penghindaran_pajak_properti/\#.VLc4BBat_IU diakses pada tanggal 15 November 2018, 10.06 WIB.

Sufia \& Riswandari (2018), Pengaruh Manajemen Laba, Proporsi Komisaris Independen, Profitabilitas, Capital Intensity, Dan Likuiditas Terhadap Tax Aggressiveness (Studi Empiris Pada Perusahaan Manufaktur Yang Terdaftar Di Bursa Efek Indonesia Tahun 2012-2016), Jurnal Akuntansi Bisnis,(11) 2, 140-156.

Sukmawati, F., \& Rebecca, C. (2016). pengaruh likuiditas dan leverage terhadap agresivitas pajak perusahaan pada perusahaan industri barang konsumsi di bursa efek indonesia periode 2011-2014. Conference on Management and Behavioral Studies Universitas Tarumanagara .

Wicaksono, A. P. (2017). Koneksi Politik dan Aggresivitas Pajak: Fenomena di Indonesia. Akuntabilitas: Jurnal Ilmu Akuntansi, (10)1 , 167-180.

Yusuf, Burhanuddin. 2015. Manajemen Sumber Daya Manusia Di Lembaga Keungan Syariah. Jakarta: Raja Grafindo Persada.

Zhang, H., Jian, M., \& Li, W. (2012). How does state ownership affect tax avoidance? Evidence from China. Working paper. School of Accountancy, Singapore Management University. 
AGRESIVITAS PAJAK YANG DIPENGARUHI OLEH KOMPENSASI EKSEKUTIF, KONEKSI POLITIK, PERTUMBUHAN PENJUALAN, LEVERAGE DAN PROFITABILITAS

Ernie Riswandari ${ }^{1)}$, Kevin Bagaskara ${ }^{2)}$

\section{Lampiran}

Statistik Deskripstif

\begin{tabular}{llllll}
\hline Variabel & Obs & Mean & Std. deviasi & Min & Max \\
\hline $\begin{array}{l}\text { Kompensasi } \\
\text { eksekuitf }\end{array}$ & 120 & 23.63958 & 1.043885 & 20.89 & 26.18 \\
\hline Koneksi politik & 120 & .375 & .4861528 & 0 & 1 \\
\hline $\begin{array}{l}\text { Pertumbuhan } \\
\text { penjualan }\end{array}$ & 120 & .1084167 & .1993519 & -0.3 & .9 \\
\hline $\begin{array}{l}\text { Leverage } \\
\text { Profitabilitas }\end{array}$ & 120 & .4446667 & .2297932 & .07 & .84 \\
\hline Agresivitas Pajak & 120 & .0910833 & .0687682 & .01 & .41 \\
\hline
\end{tabular}

Sumber: Hasil pengolahan di STATA 14.2

Hasil Pengujian Regresi Linier Berganda

\begin{tabular}{l|ccc} 
Source & SS & $\mathrm{dF}$ & $\mathrm{MS}$ \\
\hline Model & .3692044211 & 5 & .073840884 \\
Residual & 1.38027559 & 114 & .012107681 \\
\hline Total & 1.74948001 & 119 & .014701513
\end{tabular}

$\begin{array}{ccc}\text { Number of obs } & =120 \\ \text { F }(5,114) & =6.10 \\ \text { Prob }>\text { F } & =0.0000 \\ \text { R-Squared } & =0.2110 \\ \text { Adj R-squared } & =0.1764 \\ \text { Root MSE } & =.11003\end{array}$

\begin{tabular}{l|cccccc}
\hline $\begin{array}{l}\text { Agresivitas } \\
\text { pajak }\end{array}$ & coef & Std. Err & $\mathrm{t}$ & $\mathrm{P}>|\mathrm{t}|$ & {$[95 \%$ conf } & Interval] \\
\hline $\begin{array}{l}\text { Kompensasi } \\
\text { eksekutif }\end{array}$ & -.0361072 & .01191 & -3.03 & 0.003 & -.0597008 & -.0125135 \\
$\begin{array}{l}\text { Leverage } \\
\begin{array}{l}\text { Pertumbuhan } \\
\text { penjualan }\end{array}\end{array}$ & .02052659 & .0553191 & 3.71 & 0.000 & .0956792 & .3148526 \\
$\begin{array}{l}\text { Koneksi } \\
\text { politik }\end{array}$ & .0531924 & .0246889 & 2.15 & 0.033 & .0042839 & .1021009 \\
$\begin{array}{l}\text { Profitabilitas } \\
\text { cons }\end{array}$ & .3515534 & .186376 & 1.89 & 0.062 & -.017656 & .7207629 \\
\hline
\end{tabular}

Sumber : Hasil pengolahan di STATA 14.2 